\title{
Die tekskritiek van die Nuwe Testament (2): 'n Oefening in teorie en praktyk*
}

L D Jacobs

Abstract

The textual criticism of the New Testament (2): An exercise in theory and practice

This concluding article on New Testament textual criticism focuses on the practical application of a workable method for the evaluation of textual variants in the manuscripts of the New Testament. Six variation units displaying a wide variety of textual problems are discussed, viz the ending of Mark's gospel, the theological/christological problem in John 1:18, the possible conjectural emendation in Acts 16:12, the ortographical variation in Romans 5:1, the doxology at the end of Romans, and the so-called "command to silence" in 1 Corinthians 14:34-35. The nett result in each case does not necessarily produce rousing new insights, but it underlines the need for a balanced approach which weighs all the evidence without prejudice before making a decision on the value of a textual variant.

$1 \quad$ Inleiding

Die besinning oor die metodologie van die Nuwe-Testamentiese tekskritiek in deel 1 van hierdie studie het aangetoon dat die gematigde eklektiese metode as breë gedagterigting tans die mees gemotiveerde en kontroleerbare tekskritiese oplossings bied $^{1}$, alhoewel die metode steeds met definitiewe voorbehoude en inagneming van sy tekortkominge toegepas behoort te word ${ }^{2}$.

In hierdie artikel wil ek poog om die kriteria van eksterne, intrinsieke en transkripsionele getuienis in die praktyk toe te pas. Gesien dat nagenoeg $60 \%$ van die variasie-eenhede in die UBS ${ }^{3}$-teks se tekskritiese apparaat 'n $\{C\}$ of $\{D\}$ gradering het en dus 'n redelike mate van onsekerheid vertoon ${ }^{3}$, is die ses probleme wat hier aangespreek word, maar 'n druppel in die emmer. Tog raak die variasieeenhede 'n wye verskeidenheid tekstuele probleme en verteenwoordig dit van die belangrikste en oudste neute wat die voornemende tekskritikus nog altyd gehad het om te kraak.

By die aanpak van so 'n studie is dit natuurlik altyd raadsaam om die woorde van Bruce $M$ Metzger deurgaans in gedagte te hou: "In textual criticism, as in other areas of historical research, one must seek not only to learn what can be known, but also to become aware of what, because of conflicting witnesses, cannot be known"4.

\footnotetext{
"Hierdie artikel is 'n verwerking van 'n werkstuk wat ingedien is as deel van die vereistes vir die M Div-graad aan die Universiteit van Pretoria onder studieleiding van Prof A B du Toit.
} 


\subsection{Inleidende opmerkings}

Waar eindig Markus se evangelie? Viljoen het die volgende alternatiewe genoem: die "stomp slot", die "kort slot", die "lang slot", die "gemengde slot" en die "uitgebreide slot"5. Die tekskritiese apparaat lyk soos volg:

\subsection{Tekskritiese apparaat}

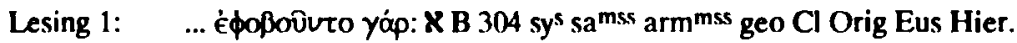

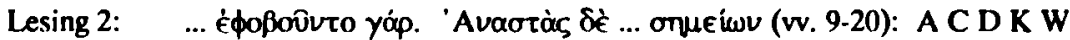
$X \Delta \theta$ II f13 28335657008921071 Byz vl vg sy cop goth armmss geo ethmss Diat Ir Tert.

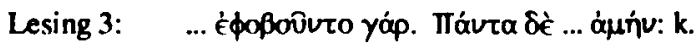

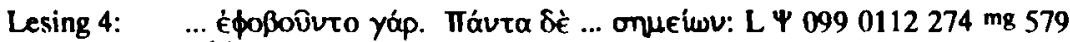
syh(mg) samss bo mss ethmss.

\subsection{Eksterne getuienis}

Die eksterne getuienis ten gunste van lesings 3 en 4 is uiters skraps en dit lyk onwaarskynlik dat een van dié twee die oorspronklike slot was.

Tussen 1 en 2 lyk die getuienis soos volg:

\section{(a) Datering}

Die oudste getuienis ten gunste van lesing 1 is die 4 e eeuse $X$ en $B$ en die Sahidiese vertaling uit die $3 \mathrm{e}$ eeu. Steun vir die lang slot - lesing 2 - kom van die 5 e eeuse kodekse A, C en D. Tog blyk dit dat Justinus al so vroeg as teen die middel van die tweede eeu kennis dra van die lang slot ${ }^{6}$.

\section{(b) Geografiese verspreiding}

Lesing 1 kom geografies nie so wydverspreid voor nie. Die teksgetuienis is hoofsaaklik in Egipte gesentreer. Daarenteen geniet die lang lesing 'n wye geografiese verspreiding deurdat dit in al die gebiede voorkom.

\section{(c) Genealogiese verwantskap}

Hier swaai die steun sterk in die guns van lesing 1 wat in die beste manuskripte, $X$ en B, voorkom, terwyl lesing 2 wel in al 4 teksfamilies voorkom, maar slegs in sekondêre verteenwoordigers van die Alexandrynse teksfamilie 7 . Hoewel die geografiese verspreiding ten gunste van lesing 2 tel, lyk dit tog of die eksterne getuienis oorwegend in die rigting van lesing 1 as die meer oorspronklike lesing lè. 


\subsection{Transkripsionele getuienis}

Lesings 3 en 4 kan maklik buite rekening gelaat word omdat in beide gevalle dit duidelik pogings verteenwoordig om 'n gepaste slot vir Markus te bied. Petzer is van mening dat die transkripsionele getuienis lesing 1 sterker ondersteun, aangesien daar geen oortuigende rede is waarom verse $\mathbf{9 - 2 0}$ weggelaat sou word indien dít die oorspronklike slot van die evangelie was nie ${ }^{8}$. Daarteenoor is die invoeging van die gedeelte maklik te verklaar, naamlik om die baie stomp einde van ' $n$ afgeronde slot te voorsien. Petzer beklemtoon ook met reg die feit dat lesings 3 en 4 duidelike bewys lewer dat daar heelwat skriptors was wat probleme gehad het met die evangelie wat op yớp geëindig het ${ }^{9}$.

\subsection{Intrinsieke getuienis}

In hierdie geval lewer die intrinsieke getuienis nogal 'n sterk bydrae tot die oplossing van die tekskritiese probleem. Ten opsigte van taal en styl is daar talle uitdrukkings in verse 9-20 wat nie eie aan Markus is nie. Metzger onderskei 17 sogenaamde nie-Markaanse woorde in dié gedeelte ${ }^{10}$.

Ook in terme van die teologie blyk dit volgens Petzer dat die gedeelte saamgestel is uit frases en gedagtes uit die ander evangelies, Handelinge en die Pauliniese briewe wat nie eg-Markaanse teologie is nie ${ }^{11}$. Tog moet daar ook ten opsigte van lesing 1 op intrinsieke gronde die vraag gestel word of 'n boek werklik op 'n partikel (yóp) kan eindig. Dit lyk asof die verhaal in die lug bly hang as vers 8 as die slot van die evangelie beskou word.

\subsection{Samevatting}

Op grond van die eksterne getuienis waarvolgens die beste en oudste manuskripte die stomp slot bevat en die intrinsieke getuienis wat die lang slot as vreemd tot die res van Markus aandui, moet lesings 2, 3 en 4 as nie-oorspronklik afgewys word. Tog dui die intrinsieke getuienis daarop dat lesing 1 waarskynlik ook nie die oorspronklike slot van die evangelie bevat nie.

Petzer stel voor dat ons moet aanvaar dat die oorspronklike slot van die Markusevangelie op ' $n$ baie vroeë stadium verlore geraak het en dat skriptors op talle maniere daarvoor probeer kompenseer het deur self 'n nuwe slot te skryf ${ }^{12}$.

\section{Johannes 1:18}

\subsection{Inleidende opmerkings}

Hierdie variasie-eenheid bied 'n baie interessante problematiek in die sin dat, alhoewel al hoe meer kritiese tekste die een lesing (met $\theta \in \hat{c}$ s) as meer gesaghebbend aanvaar, kommentatore en vertalers oor die algemeen steeds huiwerig bly om die lesing as die oorspronklike of as die beter lesing van die twee belangrikste lesings te aanvaar ${ }^{13}$. Die lesing het skynbaar ook aan die vertalers van die Nuwe Afrikaanse Veraling (1983) hoofbrekens besorg, aangesien hulle in die poging om die betekenis van die lesing waarvoor hulle gekies het, duideliker na vore te bring, 
in die proses ' $n$ derde lesing vertaal het ${ }^{14}$.

Die tekskritiese apparaat van die variasie-eenheid sien soos volg daar uit:

\section{$3.2 \quad$ Tekskritiese apparaat}

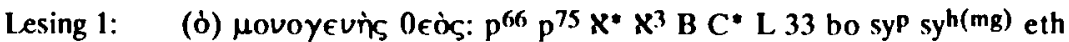
Diat Ir Cl Orig Did en 'n hele antal kerkvaders.

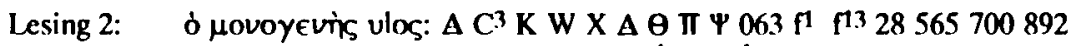
10711241 Byz Lect vl vg syc syh sypal arm eth geo en baie kerkvaders.

Lesing 3: Movoyevins vlòs $\theta \epsilon$ oû: 9 Ir Orig.

Lesing 4: ò rovoyevins: vg Diat en 'n aantal kerkvaders.

\subsection{Eksterne getuienis}

Lesings 3 en 4 dra nie veel gewig nie, aangesien hulle slegs in vertalings en patristiese aanhalings voorkom. Beide lesings kan verklaar word as 'n poging om die problematiek van $\theta$ Eos/vios op te los; lesing 3 deur middel van konflasie lesings 1 en 2 in harmonie met mekaar te bring en lesing 4 deur eenvoudig die hele probleem weg te laat ${ }^{15}$.

Tussen lesings 1 en 2 lyk die getuienis soos volg:

\section{(a) Datering}

Lesing 1 het die ondersteuning van $p^{275}$ en $p^{66}$ wat albei aan die begin van die derde eeu gedateer $k$ an word. Die vroegste getuienis vir lesing 2 is die vyfde eeuse $A$.

(b) Geografiese verspreiding

Lesing $1 \mathrm{kom}$ in alle geografiese gebiede voor, terwyl lesing 2 beperk is tot veral Westerse bronne.

(c) Genealogiese verwantskap

Met die steun van $\mathrm{p}^{66}$ en $\mathrm{p}^{75}$ asook $\mathrm{X}, \mathrm{B}, \mathrm{C}$ en $\mathrm{L}$ is dit duidelik dat lesing 1 die beste teksgetuienis geniet. Lesing 2 het daarenteen vanaf vroeë Westerse bronne deur middel van vermenging sy weg tot eers die Caesareaanse en later die Bisantynse teks gevind.

Dit is dus duidelik dat lesing 1 in al die vroegste en beste bronne voorkom en 'n goeie vroeë geografiese verspreiding geniet.

\subsection{Transkripsionele getuienis}

Wanneer gevra word na die difficilior lectio is dit duidelik dat lesing 1 ( $\theta \in \mathrm{G} \mathrm{S}$ ) hier 
die moeilikste lesing is. McReynolds meld dat lesing 2 twee latere parallelle in die Johannesevangelie het, sodat 'n skriptor heel moontlik in Johannes 1:18 'n moeiliker lesing na 'n meer tradisionele lesing kon verander het ${ }^{16}$.

Petzer noem ook die moontlikheid dat 'n skriptor in die ontwikkeling van die teologie rondom Jesus kon gepong het om die kontras tussen Vader en Seun in die vers sterker te beklemtoon. Daarenteen is daar geen duidelike rede waarom

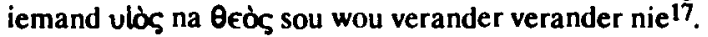

Die oorwig van die transkripsionele getuienis lê dus ook in die rigting van lesing 1.

\subsection{Intrinsieke getuienis}

In terme van intrinsieke getuienis is daar 'n verskeidenheid van standpunte. Die basiese argument van diegene wat kies vir lesing 2 (ulòs) is dat dit meer in lyn is met Johannes se gebruik in die konteks van die proloog. Hierdie geleerdes aanvaar oor die algemeen dan ook dat die eksterne getuienis lesing 1 sterk ondersteun, maar kies steeds vir lesing 2 as die beter lesing op grond van hulle verstaan van die konteks ${ }^{18}$.

\subsection{Samevatting}

Veral uit die pogings wat vertalers aangewend het om 'n konflasie tussen lesing 1 en 2 te bewerkstellig - McReynolds lys 'n hele aantal ${ }^{19}$ - is dit duidelik dat Johannes 1:18 nog nie bevredigend uitgetrap is nie. Op grond van die sterk steun van sowel eksterne as transkripsionele getuienis kan daar egter met gerustheid vir lesing $\mathbf{1}$ - $\boldsymbol{\delta}$

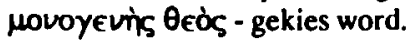

\section{$4 \quad$ Handelinge 16:12}

\subsection{Inleidende opmerkings}

Hierdie variasie-eenheid word deur die redaksie van die UBS-teks met 'n \{D\}gradering aangedui. Dit is dus duidelik dat daar glad nie eenstemmigheid onder die lede was nie. Die probleem met die lesing wat algemeen as die mees oorspronklike aanvaar word, is dat dit nie klop met wat bekend is van die status van die stad Filippi nie. Die tekskritiese apparaat lewer die volgende op:

\subsection{Tekskritiese apparaat}

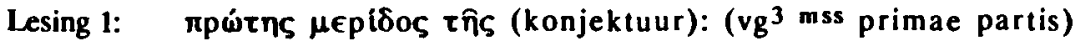
Provencal Old German.

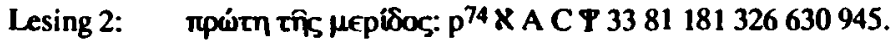

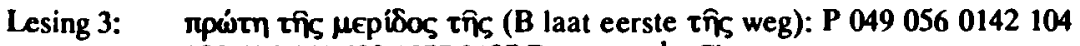
33043645162918772127 Byz copsa, bo Chrys.

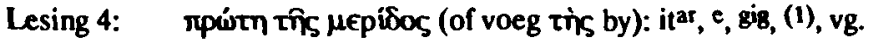




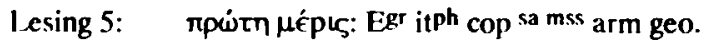

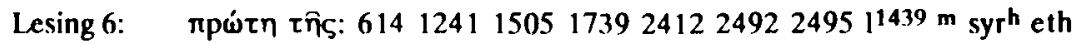
Chrys.

Lesing 7: KEфoגin tîs: $D$ it ${ }^{d}$ syrP.

\subsection{Eksterne getuienis}

\section{(a) Datering}

Feitlik al die lesings het redelik vroeë getuienis ter ondersteuning alhoewel die oudste teksvariant in die bestaande Griekse manuskripte skynbaar lesing 2 is (met $\boldsymbol{X}$ A en $\mathrm{C}$ ).

\section{(b) Geografiese verspreiding}

Lesing 2 se meeste steun is in Egipte gesetel, maar dit geniet tog nog die wydste geografiese steun.

\section{(c) Genealogiese verwantskap}

Sterk teksgetuies soos $p^{74}, K, A, C$ en 81 bied aan lesing 2 "overwhelming manuscript evidence" 20 . Lesing 3 word wel deels deur $B$ gesteun, maar dit beïnloed nie werklik die probleem van die variasie-eenheid direk nie.

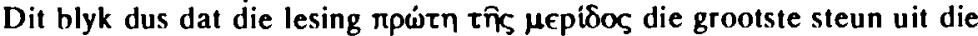
eksterne getuienis kry.

\subsection{Transkripsionele getuienis}

Lesing 2 skep egter probleme. Word rpútr vertaal met "hoof" soos in hoofstad dan bots dit met die feit dat Tessalonika die hoofstad van Masedonië was en Amfipolis die hoofstad van die streek waarin Filippi geleë was. Dit kan ook nie beteken dat dit die eerste stad was wat Paulus in Masedonië besoek het nie, want hy het Neapolis eerste aangedoen. Dit kan ook 'n aanduiding van 'n bepaalde status wees, maar ook dit lewer bepaalde probleme. Die RSV het uiteindelik gekies vir 'n posisie waarin roútn bloot "a leading city"21 beteken.

Al hierdie vertalings- en interpretasieprobleme het skriptors egter daartoe

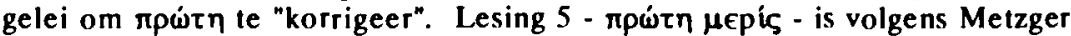
onmoontlik omdat 'n stad nie 'n $\mu \in$ í $_{5}$ genoem kan word nie 22 . Lesing 6 wat Filippi

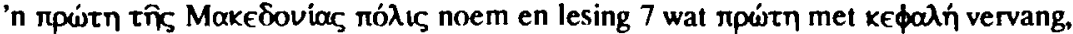
vererger net die probleem. Laasgenoemde word allerweë as 'n Latinisme beskou ${ }^{23}$.

Hierdie variasie-eenheid word deur sommige geleerdes gesien as dié een plek in die Nuwe Testament waar konjekturale emendasie benodig word ${ }^{24}$, wat

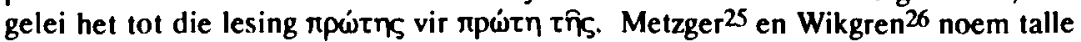
groot name soos Le Clerc, Blass, Field en Turner wat die konjektuur voorgestaan het, terwyl die meerderheid van die UBS-komitee ook die mening toegedaan was. 
As verklaring vir die ontstaan van die tradisionele lesing voer dié geleerdes aan dat reduplikasie van die letters $t \eta$ of 'n verkeerde interpretasie van die korreksie van

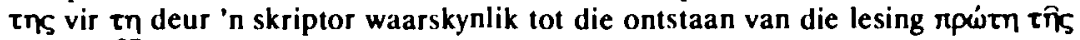
gelei het ${ }^{27}$.

\subsection{Intrinsieke getuienis}

Talle oplossings is reeds aangebied vir 'n sinvolle interpretasie van Filippi as $\pi$ pútn roגis. Wikgren onderstreep ook dat talle van die pogings tot "geographical identification" meer aandag verdien as wat dit tot op hede geniet het ${ }^{28}$. Vir die meeste van die verklaringsmoontlikhede is daar egter net nie genoeg steun van byvoorbeeld muntstukke of ander inskripsies nie.

Op die uiteindelike vraag na wat die skrywer van Handelinge na alle waarskynlikheid sou geskryf het, lyk dit asof die voorgestelde emendasie intrinsiek tog die beste oplossing bied. Dit gee 'n presiese beskrywing van die status van die stad Filippi in die tyd wat Handelinge waarskynlik geskryf is, naamlik as "a city of the first district of Macedonia"29.

\subsection{Samevatting}

Aangesien dit so moeilik is om die getuienis van $\mathrm{p}^{74}, \mathrm{~K}, \mathrm{~A}, \mathrm{C}$, ensovoorts net maar te ignoreer en die eksterne getuienis so sterk ten gunste van lesing 2 tel, het die komitee wat die $\mathrm{UBS}^{3}$ en $\mathrm{NA}^{26}$ tekste saamgestel het, besluit om die slotsigma van rpẃtns in blokhakies te behou en so uitdrukking te gee aan die groot mate van twyfel wat rondom die lesing bestaan ${ }^{30}$. Wikgren gee egter die situasie baie raak weer as hy sê: "Most commentators, editors, and translators have been persuaded, with varying degrees of dissatisfaction, to adopt the 'Alexandrian' reading"31 (my kursivering).

\section{$5 \quad$ Romeine 5:1}

\section{$5.1 \quad$ Inleidende opmerkings}

Romeine 5:1 bied een van die gevalle waar die komitee wat verantwoordelik was vir die samestelling van die $\mathrm{UBS}^{3}$ en $\mathrm{NA}^{26}$ tekste gekies het téén 'n lesing met veel sterker eksterne ondersteuning ${ }^{32}$. Dit is ook een van die min variante waar Erwin Nestle afgewyk het van die teks wat hy by sy vader en 'n lang lys vroeëre teksuitgawes geërf het ${ }^{33}$. Die tekskritiese materiaal vir hierdie ortografiese probleem waaroor redelike onsekerheid heers (vgl die $\{\mathrm{C}\}$-gradering in die UBS), vertoon soos volg:

\subsection{Tekskritiese apparaat}

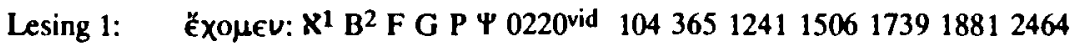
2495 pm vgmss.

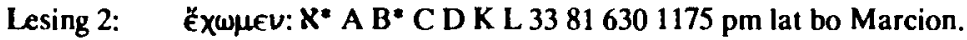




\section{(a) Datering}

Die oorspronklike én ouer lesings van $X$ en $B$ ondersteun die subjunktief, terwyl hulle latere korrektors die indikatief steun. Daarenteen tel die $3 e$ eeuse Sahidiese vertaling weer ten gunste van laasgenoemde ${ }^{34}$, terwyl die $4 \mathrm{e}$ eeuse Bohairiese verta-

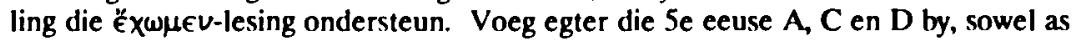
die steun van Marcion, en die skaal swaai sterk in die guns van lesing 2.

\section{(b) Geografiese verspreiding}

Lesing 2 geniet steun uit letterlik al die sentra, terwyl lesing 1 hoofsaaklik gesteun word deur manuskripte wat lokaal aan mekaar verwant is.

(c) Genealogiese verwantskap

Die steun vir die indikatief kom veral uit Bisantynse manuskripte, terwyl sowel die belangrikste Alexandrynse ( $X, B)$ as sterk Egiptiese getuies (A, C), Westerse (D) 5 én Bisantynse bronne (K, L) die subjunktieflesing ondersteun. 0220 is wel 'n sterk getuie, maar die lesing is onseker.

Dit blyk dus dat Metzger se uitspraak dat "the subjunctive ... has far better external support than the indicative ..." ${ }^{\text {.35 }}$ onderskryf kan word.

\subsection{Transkripsionele getuienis}

Die verwarring tussen e en $\eta$ en o en $\omega$ word deur Petzer toegeskryf aan klankverwarring ${ }^{36}$. Met die voorlees van manuskripte ter wille van kopiëring was dit skynbaar maklik om die o en $\omega$ klanke met mekaar te verwar - Metzger stel selfs dat "the difference in pronunciation between $o$ and $\omega$ in the Hellenistic age was almost non-existent"37. Moir is nie oortuig deur die standpunt dat 'n Griekse skrywer of skriptor altyd bewus was van die verskil tussen die indikatief en subjunktief nie. Hy vervolg: "I would still want an assurance that a writer or scribe could not produce an -0 - and still intend the form to be read as a subjunctive or vice-versa with $\omega^{\text {n38. }}$.

Dit is egter interessant dat Metzger die oorsaak vir die "fout" reeds voor die

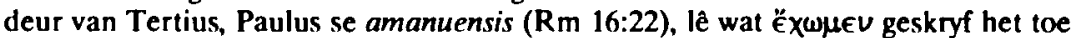

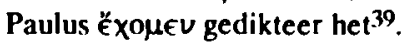

\subsection{Intrinsieke getuienis}

Die meerderheid van die redaksiekomitee was van mening dat intrinsieke getuienis hier bo eksterne getuienis moet geld. Wat wou/sou Paulus gesê het? Aland \& Aland antwoord: "Nach dem Kontext von Röm 5 und der gesamten paulinischen

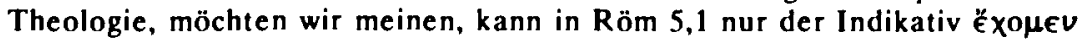
gestanden haben"40. Ook Metzger is van mening dat Paulus nie hier vermaan nie, maar feite konstateer - die vrede is die gawe aan diegene wat gereguerdig is ${ }^{41}$. Daarom sluit die indikatief beter aan by die argument van die perikoop. 
Die eksterne getuienis ondersteun lesing 2 oorwegend; die transkripsionele getuienis kan enigeen van die lesings steun - "w kann o meinen, und umgekehrt o gleich $\omega \operatorname{sein}^{\text {"42 }}$. Uit die konteks van die gedeelte blyk dit egter dat Paulus waarskynlik eerder éxojєv sou geskryf het - Ons hèt die vrede.

6 Romeine 16:25-27

\subsection{Inleidende opmerkings}

Sowel die outentisiteit as die korrekte plasing van die doksologie aan die einde van die Romeinebrief het al heelwat interpretasieprobleme aan tekskritici en eksegete besorg. Die opskrif van die kommentaar oor hierdie gedeelte in Käsemann lui selfs: "Inauthentic concluding doxology (16:25-27) ${ }^{43}$ (my kursivering). Wat die oplossing van die probleem moeiliker maak, is die feit dat dit nie 'n suiwer tekskritiese probleem is nie, maar heelwat wyer eksegetiese raakpunte het.

Die tekskritiese apparaat lyk soos volg:

\subsection{Tekskritiese apparaat}

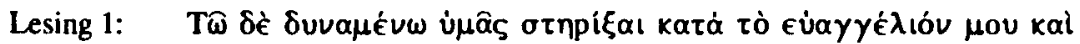

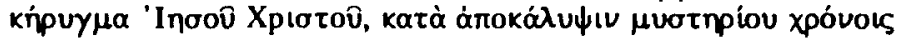

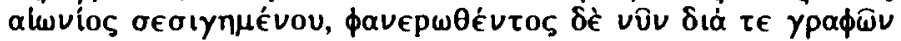

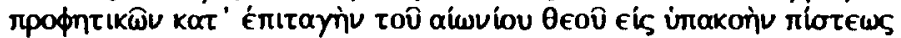

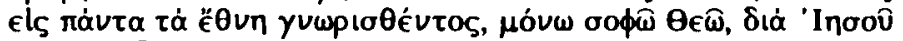

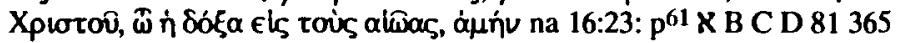
63017392464 it vg sa bo eth C1 Orig Ambst.

Lesing 2: TÐ̋ $\delta \dot{e} . .$. na 16:23 en na 14:23: A P 53388104 arm.

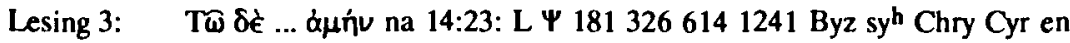
enkele kerkvaders.

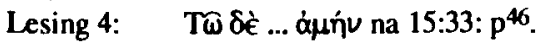

Lesing 5: Weglating: F G $629 \mathrm{~g}$ goth Marc.

6.3 Eksterne getuienis

(a) Datering

Lesing 1 word deur die oudste bronne ondersteun; $X$ en $B$ uit die vierde eeu, die vyfde eeuse $\mathrm{C}$ en die derde eeuse Sahidiese vertaling. Al die ander lesings kom slegs in laatgedateerde bronne voor ${ }^{44}$. 
Ook hier lê die oorwig van getuienis by lesing 1 wat die wydste geografiese verspreiding het.

\section{(c) Genealogiese verwantskap}

Die beste manuskripte ondersteun lesing 1, naamlik $p^{61}, X, B, C$ en sa. Die steun vir die ander lesings is of laat gedateer of baie min. Die weglating (lesing 5) word wel deur vroeëre Westerse bronne asook Marcion ondersteun. Juis die invloed van Marcion moet egter die tekskritikus op sy hoede maak omdat die doksologie in Marcion se proses van hersiening van die Paulusbriewe weggelaat kon gewees het ${ }^{45}$.

Dit is dus duidelik dat die eksterne getuienis lesing 1 sterk ondersteun.

\subsection{Transkripsionele getuienis}

In 'n poging om 'n verklaring te probeer vind vir die ontstaan van die verskillende variante lesings, lyk dit asof skriptors telkens die doksologie geplaas het aan die einde van die Romeineteks wat hulle voor hulle gehad het; skriptor 1 aan die einde van 16:23, 2 ná 14:23 en 16:23, 3 ná 14:23 en 4 ná 15:33, iets wat soos Aland \& Aland se tot "völligen Chaos" gelei het 4 . Dit sou dus nodig wees om nie net te hepaal of die doksologie oorspronklik deel was van die Romeinebrief nie, maar ook om vas te stel waar die brief oorspronklik geëindig het.

Om op transkripsionele gronde te redeneer dat die doksologie ingevoeg is om 'n gepaste afsluiting aan die brief te verleen, is problematies, omdat dit soveel anders is as die gebruiklike Pauliniese briefafsluiting. Waarom dan nie maar net by 16:23 halt roep nie?

Die transkripsionele getuienis gee dus nie vir ons 'n klinkklare antwoord oor die houdbaarheid van die doksologie in die teks nie.

\subsection{Intrinsieke getuienis}

Op grond van 'n groot aantal nie-Pauliniese taal- en stylelemente in Rom 16:25-27 kan aangevoer word dat lesing 5 ondersteun behoort te word. Hierdie verse kom egter waarskynlik uit 'n vroeë kerklike belydenis, iets wat nie onbekend in die briewe van Paulus is nie ${ }^{47}$.

\subsection{Samevatting}

Geoordeel aan die eksterne getuienis lyk dit asof lesing 1 ons keuse behoort te wees - dit is dan ook die lesing wat sy weg gevind het in ons Nuwe Afrikaanse Vertaling (1983). Veral aangesien hierdie variasie-eenheid nie die tekskritiek alleen raak nie, bly 'n finale uitspraak oor die oorspronklike of mees oorspronklike lesing uiters problematies 48 .

Dit blyk ook duidelik uit die feit dat die komitee van die UBS besluit het om die doksologie wel op sy tradisionele plek te behou, maar dit binne blokhakies te plaas om die graad van onsekerheid rondom die korrekte plasing daarvan aan te dui ${ }^{49}$. Dit is egter interessant dat Aland \& Aland die mening uitspreek dat hierdie 
gedeclte nie in die oorspronklike Romeinebrief tuishoort nie en weggelaat behoort te word, waarop hulle tong in die kies vervolg: "So bleibı hier nichts mehr zu sagen" 50 . Hurtado beskryf die huidige situasie baie goed wanneer hy opmerk: "In short, the situation calls for a scholarly 'agnosticism' and continuing research"51.

$7 \quad 1$ Korintiërs 14:34-35

\subsection{Inleidende opmerkings}

Die kwessie van wat Ellis die "silenced wives of Corinth" noem52, lewer reeds eeuelank sowel tekskritiese as teologiese probleme op. Reeds so vroeg as 1557 het die Spanjaard Juan de Valdez al indringend aandag aan dié teksgedeelte geskenk ${ }^{53}$. Die tekskritiese apparaat vir die variasie-eenheid is soos volg:

\subsection{Tekskritiese apparaat}

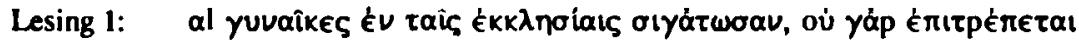

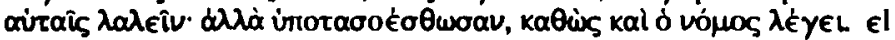

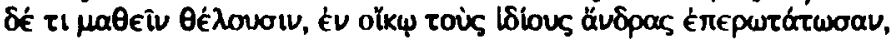

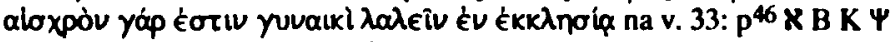
024333811043651175 Byz it vg syr cop arm.

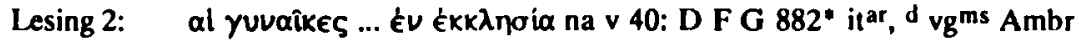
Sedulius-Scolus.

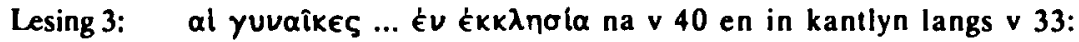
Fuldensis.

7.3 Eksterne getuienis

(a) Datering

Die meeste van die oudste manuskripte ( $p^{46} \times$ B sa) ondersteun lesing 1.

(b) Geografiese verspreiding

Die manuskripte wat lesing 1 ondersteun is versprei oor al die geografiese gebiede, terwyl lesing 2 deur hoofsaaklik Westerse manuskripte gesteun word.

\section{(c) Genealogiese verwantskap}

Ook hierdie aspek dui bo alle twyfel in die rigting van lesing 1, aangesien al die beste manuskripte die lesing verteenwoordig, lesing 2 slegs 'n paar Westerse manuskripte en lesing 3 slegs een, naamlik die sesde eeuse Kodeks Fuldensis.

Dit lyk dus asof ekstern geoordeel lesing 1 die meeste gewig dra. 
Dit blyk dat Westerse skriptors dieselfde probleem met 1 Korintiërs 14:34-35 ondervind het as wat Conzelmann stel: "This self-contained section (33b-36) upsets the context: it interrupts the theme of prophecy and spoils the flow of thought ${ }^{\mathrm{n} 54}$. Op die oog af lyk dit of die verse nie inpas binne die konteks van die hoofstuk of binne Paulus se teologie nie, veral sy standpunte in 1 Korintiërs 11:2-16. Wat egter ten opsigte van die tekskritiek gesê moet word, is dat geen manuskrip die verse uitlaat nie, sodat die egtheid daarvan nie werklik in die gedrang kom nie. Die verskuiwing van verse 34-35 soos variante lesings 2 en 3 aandui, kan dus verklaar word as 'n poging om die teks meer verstaanbaar te maak.

\subsection{Intrinsieke getuienis}

Ten spyte van die feit dat al die bekende manuskripte verse 34-35 wel bevat, is sommige geleerdes van mening dat ons hier met 'n nie-Pauliniese interpolasie te doen het ${ }^{55}$. Conzelmann lè sterk klem op die talle "linguistic and theological peculiarities" .56 in die gedeelte. Ellis bied egter ' $n$ interessante en baie oortuigende verklaring vir die probleem deur aan te voer dat die gedeelte nie 'n verbod op die openbare bediening van vrouens plaas nie, maar eerder 'n ordereëling bied vir die bediening van getroude vroue wat sal inpas by hulle verpligtinge jeens hulle mans 57 . Ter stawing hiervan stel hy die volgende:

1 ruví moet in hierdie konteks as getroude vroue ("wives") gelees word.

2 Die beginsel dat ' $n$ persoon se bediening moet inpas by sy huweliksverpligtinge is in lyn met Paulus se algemene gedagterigting.

3 Die opdrag tot stilte/orde aan die vrouens (14:34) is regulatief en nie wesenlik anders as dié gerig tot diegene wat in tale spreek $(14: 28)$ of die profeet $(14: 30)$ nie $^{58}$.

\subsection{Samevatting}

Dit blyk dus enersyds dat die eksterne manuskripgetuienis sterk steun bied aan die plasing van verse 34-35 op die gebruiklike plek en andersyds dat dié verse wel inpas in die konteks en binne Paulus se teologie. Moontlik bied lesing 3 (die voorstel van Fuldensis), indien nie die mees oorspronklike lesing nie, dan tog wel 'n moontlike aanduiding van die ontstaan van die probleem. Ellis stel byvoorbeeld die moontlikheid dat 1 Korintiërs 14:34-35 'n kantlynnota in die outografon van die eerste Korintiërbrief was 59 . In die afwesigheid van voldoende getuienis is daar egter geen rede om die verse as ' $n$ nie-Pauliniese glos af te mak nie ${ }^{60}$.

\section{Slot}

Die tekskritiese metodologie blyk nog lank nie in 'n skaakmatsituasie te verkeer nie. Daarvoor bied een kyk na die oorvloed onopgeloste en onuitgetrapte probleme genoeg bewys. Epp maan ook dat ons nie moet moed opgee nie, aangesien nuwe 
manuskripvondste dalk nog al die kaarte kan kom deurmekaar krap ${ }^{61}$.

In die soeke na 'n verantwoorde tekskritiese metodologie, blyk die antwoord te Ie in 'n gebalanseerde benadering. Daar kan dus nie bloot aan die een kant volstaan word met 'n slaafse navolging van manuskripte soos $\mathbf{X}$ en $\mathbf{B}$ nie. Aan die ander kant moet ook weer daarteen gewaak word om oorhaastige en ongekontroleerde uitsprake op grond van die sogenaamde styl van 'n bepaalde outeur te maak. Met talle nuwe ontwikkelinge op die terrein van die linguistiek en die literatuurwetenskap wat tans al groter invloed op die Nuwe-Testamentiese wetenskap begin uitoefen, kan die Tekskritiek as vak nie onaangeraak bly nie. Dit is dus noodsaaklik dat tekskritici ook deeglik op hoogte sal bly van sodanige ontwikkelinge in ander vakrigtings. Ek deel egter Epp se optimisme oor die toekoms van die vakgebied wanneer hy sê: "The discipline of NT textual criticism, with or without new MS discoveries, has a promising and vibrant future, but let us hope that the pessimism regarding fresh discoveries will not find fulfillment and that younger scholars will be taught, rather, to look to the future with expectation and optimism"62.

\section{NOTAS}

1 Vergelyk J H Petzer, Nuwe-Testamentiese tekskritiek sedert 1881: 'n Kritiese evaluering van die belangrikste metoderigtings, met besondere verwysing na die laaste gedeelte van die twintigste eeu, D Litt-proefskrif, PU vir CHO 1987, 202.

2 Vergelyk Petzer, $a w$ 199-202.

3 Vergelyk E J Edwards, "On using the textual apparatus of the UBS Greek New Testament", The Bible Translator vol 28 (1977), 122.

4 B M Metzger, The text of the New Testament: Its transmission, comuption, and restoration, Oxford 21968, 246.

$5 \quad$ P H Viljoen, Die slot van Markus, Honneursskripsie, PU vir CHO 1984, 1.

$6 \quad$ Metzger, $a w 227$.

$7 \quad$ Vergelyk Viljoen, $a w 13$

8 J H Petzer, Die teks van die Nuwe Testament: 'n Inleiding in die basiese aspekte van die teorie en praktyk van die tekskritiek van die Nuwe Testament, Pretoria 1990, 243.

9 Petzer, $a w, 1990,243$.

$10 \quad$ Metzger, $a w, 1968,227$.

11 Petzer, $a w, 1990,243$.

12 Petzer, $a w, 1990,243$; so ook Metzger, $a w, 228$. 
13 Vergelyk P R McReynolds, "John 1:18 in textual variation and translation", E J Epp \& G D Fee (eds). New Testament textual criticism: Its significance for exegesis: Essays in honour of Bnuce M Metzger, Oxford 1981, 105.

14 Vergelyk Petzer, $a w, 1990,248$.

15 Petzer, $a w, 1990,247-248$.

16 McReynolds, $a w, 114$.

17 Petzer, $a \boldsymbol{w}, 1990,248$.

18 Vergelyk McReynolds, $a$ w, 117.

19 McReynolds, $a w, 117$.

20 B M Metzger, A textual commentary on the Greek New Testament, Corr ed, London-New York 1975, 446.

21 Metzger, $a w, 1975,445$.

22 Metzger, $a w, 1975,445$.

23 Vergelyk A P Wikgren, "The problem in Acts 16:12", in Epp \& Fee (eds), $a$ $w, \quad 175$ en Metzger, $a w, 1975,446$.

24 Vergelyk byvoorbeeld Petzer, $a$ w, 1990, 226-227.

25 Metzger, $a w, 1975,446$.

26 Wikgren, $a w, 173$.

27 Vergelyk Metzger, $a w, 446$.

$28 \quad$ Wikgren, $a w, 177$.

29 Vergelyk Wikgren, $a w, 178$ en Petzer, $a w, 1990,227$.

$30 \quad$ Metzger, $a w, 1975,446$.

31 Wikgren, $a w, 175$.

$32 \quad$ Metzger, $a w, 1975,511$.

33 Vergelyk K Aland \& B Aland, Der Text des neuen Testaments. Einführung in die wissenschaftlichen Ausgaben sowie in Theorie und Praxis der modernen Textkritik, Stuttgart 1982, 288.

34 Vergelyk die UBS-apparaat.

$35 \quad$ Metzger, $a w, 1975,511$.

$36 \quad$ Petzer, $a w, 1990,53$. 
37 Metzger, $a w, 1975,511$.

38 I A Moir, "Ortography and theology: The omicron-omega interchange in Romans 5:1 and elsewhere", in Epp \& Fee (eds), $a$ w, 181.

39 Metzger, $a w, 1975,511$.

$40 \quad$ Aland \& Aland, $a w, 288$.

41 Metzger, $a w, 1975,511$.

$42 \quad$ Aland \& Aland, $a w, 288$.

43 E Käsemann, Commentary on Romans, Translated by G W Bromiley, London 1980, 421.

$44 \quad$ Petzer, $a$ w, 1990, 259.

45 Vergelyk Petzer, $a w, 1990,259$.

46 Aland \& Aland, $a w, 297$.

47 Vergelyk Petzer, aw, 1990, 259.

48 Vergelyk Petzer, $a w, 1990,260$ en L W Hurtado, "The doxology at the end of Romans" in Epp \& Fee (eds), a w, 199.

49 Vergelyk Metzger, $a w, 1975,536$.

50 Aland \& Aland, $a w, 312$.

S1 Hurtado, $a w, 199$.

52 E E Ellis, "The silenced wives of Corinth (1 Cor 14:34-35)" in Epp \& Fee (eds), $a w, 213$.

53 J de Valdez, La primera epístula de San Pablo Apóstol a los Corintios, Venezia 1557, 267-268.

54 H Conzelmann, 1 Corinthians, Translated by J W Leitch, Philadelphia 1975, 246.

55 So byvoorbeeld Conzelmann, $a w, 246$ en C K Barrett, The first epistle to the Corinthians, London 21971, 329-333.

S6 Conzelmann, $a w, 246$.

57 Ellis, $a w, 217$.

58 Ellis, $a$ w, 217-218. Vergelyk hiervoor ook J H Smit, "Die 'swyggebod' en die vrou in die amp: Kantaantekeninge by 1 Kor 14:34-35 en 1 Tim 2:11-12", Acta Theologica vol 9 (1989), 26-27. 
$59 \quad$ Ellis, $a w, 219$.

60 Vergelyk Ellis, $a w, 220$.

61 E J Epp, "New Testament textual criticism past, present, and future: Reflections on the Alands' Text of the New Testament", Hanvard Theological Review vol 82 (1989), 229.

$62 \quad$ Epp, $a w, 1989,299$. 